\title{
http://dx.doi.org/10.18778/2080-8313.18.04
}

Dariusz Wegrzyn

(BBH IPN Katowice)

\section{DZIEJE OBOZU NKWD / MWD NR 503 KEMEROWO, ZE SZCZEGÓLNYM UWZGLĘDNIENIEM POBYTU W NIM OSÓB ARESZTOWANYCH W EUROPIE ŚRODKOWO- -WSCHODNIEJ W 1945 ROKU}

$1 \begin{aligned} & \text { rmia Czerwona wkraczając na obszar Europy Środkowo-Wschodniej } \\ & \text { z jednej strony stopniowo wypierała stamtąd wojska III Rzeszy, ale } \\ & \text { równocześnie wprowadzała na zajętych terenach swoje własne porządki, }\end{aligned}$ realizując politykę faktów dokonanych. Józef Stalin w oparciu o sukcesy militarne budował swą strefę wpływów w Europie, a na zajętych terenach tworzące się rządy państw w nowych granicach były lub też szybko się stały w pełni zależne od Moskwy ${ }^{1}$. Oczywiście było to możliwe dzięki obecności na tych terenach żołnierzy Armii Czerwonej i funkcjonariuszy NKWD. Z tym wiązały się represje wobec osób sprzeciwiających się narzucaniu nowych porządków i rządów komunistycznych. Jedną z kluczowych form prześladowań stało się aresztowanie przez sowiecki aparat represji mieszkańców Europy Środkowo-Wschodniej, a następnie kierowanie zatrzymanych do sowieckich łagrów położonych w odległych rejonach ZSRS. Należy podkreślić, że aresztowanym zazwyczaj nie przedstawiano zarzutów w postaci aktu oskarżenia, a następnie nie rozpatrywano ich spraw przed sądami. Bez wyroku przebywali w łagrach nie mając świadomości, jak długo potrwa ich pobyt i niejednokrotnie nie wiedząc, co było przyczyną ich zatrzymania. Jednym z takich obozów, do których trafiali, był łagier o numerze 503 ulokowany w Kemerowie - na obszarach zachodniej Syberii². Niniejszy artykuł jest próbą odtworzenia historii tego obozu i wskazania na losy osób cywilnych tam osadzonych, z których znaczna część pochodziła z terenów zachodniej części przedwojennej II Rzeczypospolitej. Niestety, cywile, którzy pod koniec II wojny światowej trafili do sowieckiego systemu obozów jenieckich z racji swej stosun-

\footnotetext{
${ }^{1}$ O budowaniu strefy wpływów przez ZSRS w Europie Środkowej i Wschodniej szerzej zob.: J. Holzer, Europa zimnej wojny, Kraków 2012, s. 17-33.

${ }^{2}$ Kemerowo [ros. Кемерово, do 1932 Szczegłowsk (ros. Щегловск)] - miasto nad rzeką Tom w zachodniej Syberii powstałe w 1925 r. Ważny ośrodek Kuzbasu (Kuźnieckiego Zagłębia Węglowego), centrum górnictwa węgla kamiennego i przemysłu maszynowego.
} 
kowo skromnej liczby, oczywiście w porównaniu z liczbą jeńców, pojawiają się w sowieckich dokumentach stosunkowo marginalnie, co utrudnia badanie tego zagadnienia.

\section{Aresztowania}

W postępowaniu władz sowieckich na zajmowanych ziemiach przedwojennej II Rzeczypospolitej widać wyraźnie odmienne podejście do terenów położonych na wschód od linii Bugu. Tam bowiem stosowano politykę faktów dokonanych - internując żołnierzy Armii Krajowej (AK) i zatrzymując mieszkańców tych ziem oraz traktując ich jako obywateli ZSRS. Po przekroczeniu Bugu widać, że rozpoczął się etap tworzenia pozorów legalności działań. W pierwszym rzędzie powstał Polski Komitet Wyzwolenia Narodowego (PKWN), który stał się dla Sowietów ,partnerem” w rozmowach i bilateralnych umowach. To PKWN legitymizował sowieckie bezprawie. W dniu 26 lipca 1944 r. podpisano w Moskwie porozumienie o stosunkach miedzy dowództwem sowieckim a polską (zależną od PKWN) administracją na terytorium Polski³, oczywiście rozumianym jako obszary położone na zachód od linii Curzona. Moskwa uznawała PKWN za jedyny organ władzy „polskiej” na zajmowanych obszarach, który był upoważniony do tworzenia administracji terenowej. Kluczowe były jednak zapisy o uprawnieniach strony sowieckiej. Mianowicie we wszystkich sprawach dotyczących wojny na terytorium Polski, najwyższa władza znajdowała się w rękach naczelnego wodza wojsk sowieckich. Co więcej, miało to mieć miejsce „W okresie niezbędnym dla przeprowadzenia operacji wojennych". Niezwykle ważna była także sprawa jurysdykcji sądowej - przestępstwa popełnione w strefie operacji wojennych podlegały prawodawstwu naczelnego dowództwa Armii Czerwonej. Tym samym PKWN dopuścił, by na kontrolowanym przez swoją administrację terenie Sowieci mogli działać swobodnie - aresztując, a potem skazując w sowieckich trybunałach obywateli polskich. Dokument ten nie zawierał katalogu przestępstw, które miały podlegać sowieckiemu prawodawstwu, czasu, kiedy owa jurysdykcja miała obowiązywać i de facto obszaru, na którym można było ją realizować, bowiem pojęcie „strefa operacji wojennych” mogło być przez władze ZSRS interpretowane dowolnie 4 .

Problem rozgraniczenia uprawnień sowieckiej administracji wojskowej od administracji tworzonej przez ,władze lubelskie” stał się przedmiotem dyskusji w Moskwie. W dniach 14-20 lutego 1945 r. do stolicy ZSRS udała się delegacja Krajowej Rady Narodowej (KRN) i Rządu Tymczasowego. Efektem tych konsultacji było postanowienie Państwowego Komitetu Obrony ZSRS (GKO - Гocy-

${ }^{3}$ W dalszej części tekstu dla uproszczenia nazywana „polską administracją”.

${ }^{4}$ A. Arkusz, Obywatele polscy w obozie NKWD-MWD ZSRR nr 178-454 w Riazaniu w latach 1944-1947, Kraków 2010, s. 66-67; M. Golon, Polityka radzieckich władz wojskowych i policyjnych na Pomorzu Nadwiślańskim w latach 1945-1947, Toruń 2001, s. 22-23. 
дарственный Комитет Обороны СССР) nr 7558 ss „О zachodniej i północnej granicy Polski, o tymczasowym polskim rządzie"5.

W dokumencie tym terytorium Polski określono jako obszary położone na zachód od linii Bugu wraz z terenami postulowanymi na zachodzie i północy. W Moskwie ustalono, że pas położony za frontem o głębokości 60-100 km miał podlegać sowieckiej administracji wojskowej. Od dobrej woli Sowietów miało zależeć zatem, czy na tym obszarze mogła działać (jako czynnik wspomagający) administracja „Polski lubelskiej”. Na pozostałych terenach mogli już samodzielnie operować polscy urzędnicy, ale Sowieci zachowali tam prawo do nadzoru nad całkowicie zmilitaryzowaną koleją i innymi liniami komunikacyjnymi, służącymi zaopatrzeniu cywilnych i wojskowych instytucji sowieckich. Równocześnie przy poszczególnych frontach i armiach powołano sowieckich ,pełnomocników Rządu Tymczasowego RP”, którzy mieli być odpowiedzialni za rozwiązywanie konfliktów między sowieckimi władzami a polską administracją oraz zajmować się problemami zaopatrzenia dla Armii Czerwonej ${ }^{6}$.

Umowa moskiewska z lipca 1944 roku i decyzja GKO z lutego następnego roku traktowane były przez władze sowieckie jako podstawy prawne działalności swoich organów policyjnych (NKWD) oraz Armii Czerwonej (w tym kontrwywiadu wojskowego „Smiersz”) na ziemiach polskich (w nowych granicach). Niezależnie od bardzo nieprecyzyjnych zapisów, Sowieci swobodnie operowali na omawianym obszarze, czego dowodem może być funkcjonowanie 64 . Zbiorczej Dywizji Wojsk Wewnętrznych NKWD

Fala aresztowań, realizowanych przez NKWD i „Smiersz”, nabrała rozpędu w styczniu 1945 r. w związku z nową ofensywą Armii Czerwonej. 11 stycznia 1945 r. Ławrientij Beria wydał rozkaz nr 0016 „O przedsięwzięciach w związku z oczyszczaniem z wrogich elementów tyłów poszczególnych frontów Armii Czerwonej i wyznaczeniu pełnomocników NKWD ZSRR przy frontach". Ten dokument (wraz z rozkazami uzupełniającymi - wykonawczymi - nr 0061 i 0062 z 6 lutego 1945 r. oraz nr 00101 z 22 lutego 1945 r. r.) stał się formalną podstawą represji na masową skalę. Przy poszczególnych frontach powołano pełnomocników NKWD oraz ich zastępców, zajmujących się kontrwywiadem i ochroną tyłów. Ludzi tych wyposażono w bardzo szerokie uprawnienia, które pozwalały na stosowanie różnych form represji w zależności od warunków lokalnych (bez konieczności konsultacji z Moskwą) ${ }^{8}$.

${ }_{5}^{5}$ Государственный Комитет Обороны СССР. Постановления и деятельность 19411945 гг. Аннотированньй каталог в двух томах, Т. 2: 1944-1945, Москва 2015, с. 780.

${ }^{6}$ W. Materski, Dyplomacja Polski ,lubelskiej” lipiec 1944 - marzec 1947, Warszawa 2007, s. 65-66.

7 Szerzej zob.: П.А. Аптекарь, Внутренние войска НКВД против польского подполья. (По документам Российского государственного военного архива), [w:] Репрессии против поляков и польских граждан, Москва 1997, с. 197-206.

${ }^{8}$ Приказ НКВД СССР № 0016 о мероприятиях по очистке фронтовых тылов Красной Армии от вражеских элементов и о назначении уполномоченных НКВД СССР по фронтам, 
Rozkaz z 11 stycznia 1945 r. definiował zadania pełnomocników NKWD przy poszczególnych frontach Armii Czerwonej w następujący sposób:

\begin{abstract}
Pełnomocnicy NKWD ZSRS otrzymali zadania: w miarę przesuwania się jednostek Armii Czerwonej niezwłocznie przeprowadzić na terenach wyzwolonych z wojsk przeciwnika niezbędne działania czekistowskie, zapewniające wykrycie i aresztowanie szpiegowsko-dywersyjnej agentury niemieckich organów wywiadu, terrorystów, członków różnych wrogich organizacji, grup bandycko-powstańczych, niezależnie od narodowości i obywatelstwa; wykryć i konfiskować nielegalne radiostacje, składy broni, podziemne drukarnie i inną bazę materiałowo-techniczną, przeznaczoną do [prowadzenia] wrogiej działalności. Pełnomocnicy NKWD ZSRS otrzymali także zadanie aresztowania kadry dowódczo-operacyjnej organów policji, kadry kierowniczej więzień, obozów koncentracyjnych, wojennych komendantów, prokuratorów, sędziów śledczych i członków sadów i trybunałów wojskowych, kierowników rad i zarządów wojewódzkich, okręgowych i powiatowych, burmistrzów, członków organizacji faszystowskich, kierowników wrogich organizacji gospodarczych i administracyjnych, redaktorów gazet, autorów publikacji antysowieckich, kadry dowódczej i szeregowej armii krajów walczących z ZSRS i tak zwanej Rosyjskiej Armii Wyzwoleńczej, a także pozostałego wrogiego elementu [podkreślenie autora] ${ }^{9}$.
\end{abstract}

Z dokumentu jasno wynikało, że sowieckie organy bezpieczeństwa mogły aresztować praktycznie każdego - od żołnierzy AK po aktywnych działaczy NSDAP czy SA włącznie. Zwłaszcza było to możliwe w sytuacji dużej swobody w podejmowaniu decyzji przez poszczególnych pełnomocników NKWD. Rozkaz „O oczyszczaniu tyłów Armii Czerwonej” w swej radykalnej postaci funkcjonował trzy miesiące i został zmodyfikowany przez kolejny akt prawny (nr 00315), wydany przez Berię 18 kwietnia $1945 \mathrm{r}$. Dał on podstawę do wstrzymania wywozu aresztowanych do łagrów ZSRS, za wyjątkiem osób, które miały tam trafić „ze względów operacyjnych”. Znacznemu zawężeniu uległa także grupa osób, która miała trafić do tworzonych na miejscu sowieckich obozów. Odtąd aresztowaniu podlegali ,jedynie" członkowie:

organizacji szpiegowsko-dywersyjnych niemieckiego wywiadu; grup dywersyjnych, pozostawionych przez przeciwnika do siania zamętu na tyłach Armii Czerwonej; posiadacze radiostacji, składów broni i wszelkiej bazy materialnej potrzebnej do działalności terrorystycznej; aktywni członkowie NSDAP, przywódcy młodzieżowych organizacji faszystowskich; współpracownicy Gestapo, SD; kierownicy organów administracji, redaktorzy gazet i autorzy pism antysowieckich ${ }^{10}$.

Москва 11 яваря 1945 г., [w:] Спеииальные лагеря НКВД/МВД СССР в Германии 1945-1950 г2. Сборник документов и статей, под редакцией С.В. Мироненко, Москва 2001, с. 11-14; А.З. Гурьянов, Интернирование - один из видов советских репрессий против поляков и польских граждан, [w:] Репрессии против поляков..., с. 207-214.

9 Cytat za: Pismo L. Berii do J. Stalina o mianowaniu petnomocników NKWD ZSRS przy frontach, Moskwa 11 I 1945, [w:] Teczka specjalna J. W. Stalina. Raporty NKWD z Polski 1944-1946, wybór i oprac. T. Cariewskaja, A. Chmielarz, A. Paczkowski, E. Rosowska, Sz. Rudnicki, Warszawa 1998, s. 165-167.

${ }^{10}$ Приказ НКВД СССР № 00315 о частичном изменении приказа НКВД СССР № 0016 от 11 января 1945 г. об организаџии уполномоченными НКВД СССР по фронтам тюрем и лагерей 
Jednym z niezwykle trudnych do określenia zagadnień, związanych z akcją aresztowań osób w Europie Środkowo-Wschodniej, jest kwestia określenia skali tej akcji. W dokumentach sowieckich tę kategorię represjonowanych określano jako „internowani - aresztowani grupy »B«"11. Najczęściej liczba takich osób, które trafiły do sowieckich obozów na terenie ZSRS, oscyluje w granicach 100 tys. W zestawieniu datowanym na 17 maja 1945 r. liczba aresztowanych i skierowanych do pracy w przemyśle sowieckim określona jest na poziomie 100043 osób ${ }^{12}$. Zbieżne, co do liczby aresztowanych, dane prezentują materiały sprawozdawcze Głównego Zarządu ds. Jeńców Wojennych i Internowanych NKWD/MWD ZSRS, czyli systemu obozowego, który ich przejął. Z dokumentów tych wynika, że w okresie od marca do maja 1945 r. do ZSRS trafiło 94601 aresztowanych grupy „B”13. Znacznie niższy poziom aresztowanych podawany jest w dokumentacji organów repatriacyjnych ZSRS. Tam liczba osób zaliczanych do tej kategorii represjonowanych wynosi 66 152. Częściowo można to thumaczyć procesem tzw. filtracji, prowadzonej wśród aresztowanych. Funkcjonariusze NKWD/MWD, po przeprowadzeniu dochodzenia, przekazywali część osadzonych w obozach do batalionów pracy, zmieniając ich status na ,internowanego - zmobilizowanego (kat. »G«)". Takich osób było ponad 18 tys. Równolegle do obozów stricte jenieckich przekazano ponad 10 tys. łagierników. Działo się tak, gdy ustalono, że aresztowany został zabrany z domu jako cywil, ale wcześniej służył w wojsku niemieckim lub Volkssturmie. W przypadku ujawnienia tego faktu automatycznie zmieniał się jego status prawny na ,jeniec" i tym samym przesyłano go do obozu stricte jenieckiego ${ }^{14}$.

и о категориях лии, подлежащих аресту на территории, освобожденной от войск противника, Москва 18 апреля 1945 г., [w:] Специальные лагеря НКВД/МВД СССР в Германии..., с. 16-17.

${ }^{11}$ Wynikało to z rozkazu NKWD nr 00101 z 22 II 1945 r. Aresztowanych żołnierzy, volkszturmistów, funkcjonariuszy organów policyjnych, więzień i obozów koncentracyjnych i członków innych organizacji militarnych określono jako tzw. grupę „A” i mieli oni trafić do obozów jenieckich. Grupa „B” praktycznie obejmowała pozostałe osoby aresztowane w ramach akcji „oczyszczania tyłów Armii Czerwonej”. Osoby te mały trafić do obozów dla internowanych o oznaczeniu numerycznym powyżej 500. Do grupy „G” zaliczono „,internowanych - zmobilizowanych” Niemców zatrzymanych zgodnie z decyzją GKO z lutego 1945 r. Tych kierowano do batalionów pracy funkcjonujących przy dużych zakładach w ZSRS. Natomiast obywatele ZSRS (tzw. grupa „W”) mieli trafić do sieci Obozów Kontrolno-Filtracyjnych, gdzie w ramach tzw. filtracji miano sprawdzić ich zachowanie się w okresie okupacji (poszukiwano kolaborantów i zdrajców). А.Л. Кузьминых, Система военного плена и интернирования в СССР. Генезис, функиионировние, лагерныии onыm (1939-1956 г2.), Архангельск 2014 (на правах рукописи), с. 178.

12 Л.В. Михеева, Инностранные военнопленные и интернированные второй мирной войны в иентральном Казахстане (1941 - начало 1950-х гг.), Караганда 2010, с. 55.

${ }^{13}$ Wojskowe Biuro Historyczne, Centralne Archiwum Wojskowe w Warszawie (dalej: WBH CAW), Kolekcja akt rosyjskich, sygn. CAW VIII.800.20.320, Notatka o licznie internowanych grupy „B" osadzonych $w$ obozach dla internowanych $i$ obozach dla jeńców wojennych oraz podobozach, stan na 1 IV 1947 r., k. 140-145.

${ }^{14}$ Tamże, sygn. CAW VIII.800.20.387, Notatka o internowanych, stan na 30 XII 1949 r., k. 6-7. 


\section{Obóz nr 503. Informacje ogólne - liczba osadzonych i kadra}

Obóz nr 503 w Kemerowie należał do drugiej, obok GUŁagu, wielkiej sieci obozowej w ZSRS. Były to łagry przeznaczone dla jeńców wojennych wziętych do niewoli przez żołnierzy Armii Czerwonej w czasie II wojny światowej, a pod jej koniec dodatkowo trafili tam zmobilizowani i aresztowani cywile z Europy Środkowo-Wschodniej. System funkcjonował w latach 1939-1953 jako (Główny) Zarząd ds. Jeńców Wojennych i Internowanych NKWD/MWD ZSRS ${ }^{15}$.

Początki obozu w Kemerowie sięgają połowy 1944 r., kiedy na obszarach zachodniej Syberii rozpoczęto proces formowania trzech obozów dla jeńców wojennych i internowanych, do których zamierzano skierować wziętych do niewoli żołnierzy III Rzeszy i jej sojuszników, a także cywili aresztowanych w Europie Środkowo-Wschodniej. Cel jego powołania był ściśle „ekonomiczny”. Osadzonych w obozach zamierzano wykorzystać do pracy w tamtejszym przemyśle wydobywczym i ciężkim oraz do prac budowlanych, związanych z rozwojem miejscowej infrastruktury. W przypadku aresztowanych cywilów widać pewną sprzeczność oficjalnej propagandy sowieckiej z realiami. Wywózkę tych ludzi do ZSRS traktowano bowiem jako część „odszkodowań wojennych” (tzw. ,żywe reparacje"), jakie władze sowieckie miały pobrać od pokonanych Niemiec. Deportowani w założeniach mieli pracować na zniszczonych w toku działań wojennych i okupacji obszarach ZSRS. Jednak zachodnia Syberia nie była terenem, do którego dotarły wojska III Rzeszy, natomiast wysyłano tam do pracy cywilów i to niekoniecznie etnicznych Niemców. Rozkazem nr 001440 z 30 listopada 1944 r. powołano do życia obóz nr 162 w Kemerowie. Na jego czele (jako naczelnik zarządu obozu) stanął Stefan Iwanowicz Iwaszkin. Jego zastępcą ds. operacyjnych został kapitan Zawołotin, a do spraw reżimu i ochrony major Niewieszkin ${ }^{16}$.

${ }^{15}$ Zarząd ds. Jeńców Wojennych NKWD ZSRS (UPW NKWD ZSRS) powstał na mocy rozkazu Berii nr 0308 z 19 IX 1939 r., a od grudnia tamtego roku został przekształcony w Zarząd ds. Jeńców Wojennych i Internowanych (UPWI NKWD ZSRS). Funkcjonował do 1953 r. - najpierw na prawach samodzielnego wydziału NKWD, a od 1946 Ministerstwa Spraw Wewnętrznych (MWD). W okresie swego największego rozrostu organizacyjnego, związanego z masowym napływem jeńców wojennych do obozów (czyli w 1945 r.), uzyskał status Głównego Zarządu ds. Jeńców Wojennych i Internowanych NKWD/MWD ZSRS. W 1951 r., w związku ze zmniejszeniem się liczby jeńców w obozach, co było związane z ich repatriacją, znowu obniżono jego rangę do Zarządu ds. Jeńców Wojennych i Internowanych MWD ZSRS. Szacuje się, że przez ten system obozowy przeszło ponad 4 miliony jeńców i internowanych cywilów. Liczbę tych ostatnich szacuje się na 340-355 tys. Szerzej zob. A. Arkusz, Sowiecki system obozowy dla internowanych cywilów spoza terenów ZSRS, [w:] Wywózka. Deportacje mieszkańców Górnego Ślaska do obozów pracy przymusowej w Zwiąku Sowieckim w 1945 roku. Faktografia - konteksty - pamięć, pod red. S. Rosenbauma i D. Węgrzyna, Katowice 2014, s. 57-68.

${ }^{16}$ Stefan Iwanowicz Iwaszkin urodził się w rodzinie chłopskiej w 1904 r. we wsi Gorienka na Białorusi. Ukończył jedynie miejscową szkołę parafialną. Pracował jako parobek, pasterz oraz robotnik w miejscowym sowchozie. Przez kilka lat pracował w ukraińskich kopalniach, a w latach 
Powołując obóz władze NKWD zakładały, że jeńcy i internowani tam osadzeni będą kierowani do pracy w okolicznych kopalniach. Siedziba władz obozowych mieściła się w Kemerowie, natomiast kontyngent miał być rozmieszczony w trzech podobozach: Kemerowo, Anżero-Sudżeńsk oraz Lenińsk-Kuźnieck. Planowany rozwój łagru w 1944 r. został zastopowany z jednego prostego powodu - jeńcy i internowani cywile nie napłynęli. Dopiero w początkach 1945 r. pojawily się pierwsze (zresztą niewielkie) grupy jeńców. Wówczas zmieniono też numerację łagru na 503. Pierwszy eszelon, który przybył do obozu, liczył 400 osób, a kolejny (przyjęty 26 kwietnia 1945 r.) kolejnych 450 osadzonych. Dopiero maj 1945 r. i kapitulacja III Rzeszy przyniosły przełom. Do końca 1945 r. do obozu przyjęto w sumie 19053 jeńców i cywilów. Cechą charakterystyczną tego obozu była duża „mobilność” siły roboczej. Praktycznie statystyki osadzonych zmieniały się bardzo znacznie nawet w ujęciu miesięcznym. W 1945 r., czyli w okresie organizacji łagru, ubyło z niego 5719 osób (zmarło - 1904, odesłano do domów - 2996, skazano i odesłano do więzienia - siedmiu, a do innych obozów skierowano - 812 osadzonych). W efekcie w początkach 1946 r. obóz liczył niewiele ponad 13 tys. osadzonych ${ }^{17}$.

Zestawienie statystyczne liczby osadzonych w obozie nr 503 w latach 1945 1949 wyglądało następująco:

Tabela 1

\begin{tabular}{||c|c|c|c|c|c|c|c|}
\hline \hline Rok & \multirow{2}{*}{$\begin{array}{c}\text { Stan na } \\
\text { początek } \\
\text { roku }\end{array}$} & Przybyło & Razem & $\begin{array}{c}\text { Odesłano } \\
\text { do domów }\end{array}$ & Skazano & Zmarło & $\begin{array}{c}\text { Odesłano } \\
\text { do innych } \\
\text { obozów }\end{array}$ \\
\hline 1945 & - & 19053 & 5719 & 2996 & 7 & 1904 & 812 \\
\hline 1946 & 13334 & 929 & 6442 & 2380 & 8 & 491 & 3563 \\
\hline
\end{tabular}

1926-1928 odbył służbę wojskową w Bobrujsku. Od 1927 r. członek WKP(b) Białorusi. Od 1939 r. skierowany do pracy w organach spraw wewnętrznych. Od 1942 r. pełnił funkcje komendanta obozów NKWD (m.in. obozu nr 200 w Swierdłowsku). Dnia 1 XII 1944 r. został zatwierdzony jako komendant obozu nr $162 \mathrm{w}$ Kemerowie, który z początkiem 1945 r. zmienił numerację na 503. Poważne problemy zdrowotne przerwały jego karierę. Począwszy od kwietnia $1946 \mathrm{r}$. przebywał na zwolnieniu lekarskim, a we wrześniu (według innych danych w październiku) 1946 r. przeszedł na rentę inwalidzką. Taka forma rozwiązania stosunku pracy uchroniła go przed zwolnieniem dyscyplinarnym, gdyż z powodu ciągłej absencji w obozie ewidentnie nie panował nad tym, co się w nim działo. М.А. Орлов, Началники управления кемеровского лагеря военнопленных и интернированных № 503, [w:] Шахтерские города Кузбасса в годы Великой Отечественной войны. Материаль региональной научно-практической конференции (Прокопьевск, 28 мая 2015 г.), Кемерово 2015, с. 133-141.

17 М.А. Орлов, Кемеровский лагерь военнопленных и интернированых № 503 (19451949 г2.), Вестник Кузбасского государственного технического университета. № 1 (101), Кемерово 2014, с. 241-251. 
Tabela 1 cd.

\begin{tabular}{||c|c|c|c|c|c|c|c||}
\hline \multirow{2}{*}{ Rok } & \multirow{2}{*}{$\begin{array}{c}\text { Stan na } \\
\text { początek } \\
\text { roku }\end{array}$} & Przybyło & Razem & $\begin{array}{c}\text { Odesłano } \\
\text { do domów }\end{array}$ & Skazano & Zmarło $\begin{array}{c}\text { Odesłano } \\
\text { do innych } \\
\text { obozów }\end{array}$ \\
\hline 1947 & 7821 & 5098 & 4184 & 2966 & 46 & 162 & 1010 \\
\hline 1948 & 8735 & 4687 & 6773 & 5561 & 64 & 62 & 1086 \\
\hline 1949 & 6639 & 966 & 7615 & 5798 & 46 & 13 & 1758 \\
\hline Razem & - & 30733 & 30733 & 19701 & 171 & 2632 & 8229 \\
\hline
\end{tabular}

Źródło: Sumaryczne sprawozdanie naczelnika Zarzadu Kemerowskiego obozu nr 503 w obwodzie Kemerowo majora Dieszina z dziatalności za okres od V 1945 roku do listopada 1949 roku, Kemerowo 31 ХІІ 1949, [w:] Региональные структуры ГУПВИ НКВД-МВД СССР 1941-1951. Отчетно - информационные документы, под ред. М.М. Загорулько, Т. 5, к. 2, Волгоград 2006, c. $666-681$.

Łagier w Kemerowie był jednym z trzech obozów GUPWI NKWD/MWD funkcjonujących w obwodzie kemerowskim. Obok niego działał jeszcze obóz nr 526 Jurga (1945-1948). Był on najmniejszy z tamtejszych łagrów. Średnio przebywało w nim od 3400 do 5400 osadzonych. Obóz nr 525 Prokopiewsk (1945-1949) był największy z nich i ,przeszło przez niego” w sumie ponad 36 tys. osób, czyli o przeszło sześć tys. więcej, niż to miało miejsce w przypadku obozu nr 503. W tym ostatnim średnia liczba osadzonych wyglądała następująco: $1945 \mathrm{r}$. - 7489; 1946 r. $-9086 ; 1947$ r. $-7520 ; 1948$ r. $-10251 ; 1949$ r.- 5293 osób $^{18}$.

Dosyć ścisłe związki łączyły łagier nr 503 w Kemerowie z obozem nr 526 w Jurdze. W 1946 r. zarząd obozu nr 503 przekazał temu drugiemu pięć podobozów zlokalizowanych w Anżero-Sudżeńsku. Powróciły one pod pierwotny zarząd w 1948 r. Niewątpliwie na terenie zachodniej Syberii widać próby optymalizacji wykorzystania pracy jeńców oraz aresztowanych cywilów. Jest to zjawisko rzadko spotykane w systemie GUPWI NKWD/MWD. Starano się to jednak realizować w sposób typowy dla sowieckiego systemu. Mianowice zmieniano jednostki zarządzające, natomiast na poziomie obozu wszystko pozostawało po staremu. W efekcie wydajność pracy łagierników była niska, a odsetek niezdolnych do niej wysoki. O zmianach organizacyjnych, w wyniku których dany podobóz zmieniał

18 А.В. Бельков, М.А. Орлов, Иностранные военнопленные и интернированные как одна из волн принудительной миграции на территории Кемеровской области (1944-1950 г2.), Вестник Вятского государственного гуманитарного университета, № 4/2005, с. 66-73; Orte des Gewahrsams von deutschen Kriegsgefangenen in der Sowjetunion (1941-1956). Findbuch, Dresden-Kaseel-Moskau-München 2010, s. 73, 79, 125-129, 257, 302-303, 318. 
swoją podległość organizacyjną, nie mieli pojęcia sami osadzeni. Jest to dowód na to, że nic się w ich życiu nie zmieniło, a „racjonalizacja pracy” odbywała się tylko na papierze i była widoczna jedynie w sprawozdawczości ${ }^{19}$.

Trzeba pamiętać, że obóz nr 503 rozrastał się liczebnie do przełomu lat 1945-1946. Związane to było z napływem z Zachodu jeńców armii III Rzeszy i cywilów, a pod koniec 1945 r. i na początku 1946 r. także Japończyków. Potem można już mówić jedynie o redystrybucji siły roboczej między samymi obozami. I właśnie obwód kemerowski także i w tym względzie był wyjątkowy. Doceniając znaczenie tamtejszego przemysłu ciężkiego i wydobywczego, zgodnie z rozkazem nr 00968 z 15 września 1947 r., postanowiono znacząco zwiększyć tamtejszy „front pracy” kierując tam 11600 jeńców z innych rejonów ZSRS. Tak wiec w obwodzie kemerowskim i obozie nr 503 można zaobserwować nietypowe zjawisko. Poziom osadzonych tam łagierników prezentował pewną dynamikę i raz się zwiększał, a w innych okresach zmniejszał, co wynikało z przepływu siły roboczej. W innych rejonach ZSRS statystka zazwyczaj pokazuje maksymalne zaludnienie obozu na przełomie lat 1945-1946, a potem liczba osadzonych powoli, lecz systematycznie się zmniejszała (wyjazdy do domów, odsyłanie chorych do szpitali, zgony itp. $)^{20}$.

Niezwykle ważna, w kontekście analizowanej w artykule kwestii, jest sprawa cywilów - aresztowanych grupy „B” osadzonych w obozie w Kemerowie. Niestety, o okresie gdy stanowili oni tam znaczną grupę posiadamy niewiele danych. W zachowanym zestawieniu statystycznym z 1945 r. znajduje się informacja o odesłaniu do tego obozu 5040 aresztowanych na podstawie rozkazu „O oczyszczaniu tyłów Armii Czerwonej”. Z tej grupy do punktu docelowego dotarły 4273 osoby, a 205 osób zmarło w transporcie. Pozostaje jeszcze grupa 562 osób określona jako „,inne ubytki”. Chodzi prawdopodobnie o zwolnionych z punktów zbornych przed wyruszeniem transportu do obozów, uciekinierów w czasie jazdy konwojów na Wschód oraz chorych odesłanych do szpitali po drodze lub zaraz po przybyciu transportu na miejsce. Ta liczba bardzo radyklane spadła w ciągu 1945 r. Z jednej strony już od połowy 1945 r. odsyłano do domów osoby chore i niezdolne do

${ }^{19}$ Gdy pod koniec lat 90. XX w. deportowani do ZSRS w 1945 r. zwracali się do archiwów rosyjskich o informacje o swoim pobycie w łagrach, otrzymywali odpowiedzi, które były dla nich zaskoczeniem. Gerard Morgała otrzymał odpowiedź, że był osadzony w obozach nr 99 w Spasozawodzku, nr 39 w Dżezkazganie i obozie nr 502 w Kiengirze, podczas gdy on sam był przekonany, że cały czas przebywał w jednym obozie w Dżeskazganie. Wyjaśnieniem tej zagadki właśnie może być kwestia zmiany podległości organizacyjnej poszczególnych podobozów, o czym osadzeni w nich nawet nie mieli świadomości. Archiwum IPN w Katowicach (dalej: AIPN Ka), Akta Oddziałowej Komisji Ścigania Zbrodni przeciwko Narodowi Polskiemu, akta śledztwa nr. s 8/00/Zk t. 6, Protokót przestuchania Gerarda Morgaty, Katowice 24 I 2001 r., k. 1092-1094.

20 А.В. Бельков, М.А. Орлов, Иностранные военнопленные и интернированные как одна из волн принудительной мигращии..., с. 68. 
pracy, ale pewien wpływ na spadek aresztowanych grupy „B” miały zmiany organizacyjne. Znaczna ich cześć przebywała w podobozach w Anżero-Sudżeńsku, które zostały przekazane pod zarząd obozu $\mathrm{nr} 526^{21}$.

Później (od 1946 r.) cywile w obozie nie stanowili już znaczącej grupy. Maksymalnie ich udział w ogóle osadzonych mógł sięgać do 15\%. Precyzyjne dane posiadamy dla początków $1946 \mathrm{r}$. W styczniu tamtego roku ich liczba wynosiła 1255 (w tym około 400 kobiet), a w lutym nieznacznie wzrosła do 1358 osób. Pod względem narodowościowym tych ludzi sklasyfikowano w następujący sposób: Niemcy - 1012, Polacy - 217 oraz Czesi - 116 osób. W przypadku pozostałych brakuje danych odnośnie ich narodowości. Kolejna zauważalna zmiana miała miejsce w maju 1946 r. w związku z repatriacją części cywilów. Ich stan od tego czasu wynosił 740-750 osób. W tej grupie kobiet było około 1/3. Niemcy stanowili wówczas grupę 580 osób, Polacy - 64, natomiast Czesi około 100 osadzonych. Należy nadmienić, że sztywne trzymanie się podawanych w statystkach danych odnośnie narodowości cywilów może być mylące. Znajdował się tam bowiem znaczny odsetek osób aresztowanych na terenie Górnego Śląska czy Pomorza Nadwiślańskiego, przedwojennych obywateli II Rzeczypospolitej, których klasyfikowano z racji pograniczności części tych terenów jako Niemców. Obok nich w obozie przebywali też cywile z Prus Wschodnich oraz z Gdańska. Należy zauważyć, że po większej partii zwolnionych cywilów w połowie 1946 r., później grupa ta nie zmniejszała się już w radyklany sposób. W zestawieniach za okres styczeń - kwiecień 1947 r. było ich w obozie 610-670 osób, przy czym znacznie rzadziej zwalniano (lub też rzadziej umierały) kobiety, których odsetek w tej grupie wzrósł do $40 \%$. W lipcu tamtego roku nadal przebywało w obozie nr 503 w sumie 562 osób. Prawie wszyscy byli zgrupowani w podobozie nr 2 w Kemerowie. Wynikało to z przepisów, które nakazywały wydzielić dla nich osobną zonę obozową i z uwagi na skromną ich liczbę najłatwiej było to wykonać komasując ich w jednym miejscu. Jeszcze w początkach 1949 r. w obozie przebywało 320 takich osób. Wówczas byli to już tylko i wyłącznie mężczyźni. Wszystkich zatrzymanych kwalifikowano wtedy jako Niemców. Wkrótce zostali zwolnieni do domów w związku z likwidacją obozu ${ }^{22}$.

${ }^{21}$ Było to blisko połowa internowanych, którzy trafili w okresie 1945-1950 na obszar obwodu kemerowskiego. W tym czasie liczba takich osób wynosiła 10 506. WBH CAW, Kolekcja akt rosyjskich, sygn. CAW VIII.800.20.414, Notatka o Niemcach aresztowanych grupy „B” w zwiazku z rozkazem NKWD ZSRS nr 00101 z 22 II 1945 r., odesłanych do poszczególnych obwodów, $20 \mathrm{~V}$ 1945 r., k. 3-7; Sumaryczne sprawozdanie naczelnika UMWD obwodu Kemerowskiego generała - majora Gubina i naczelnika Zarządu OPWI majora Stukaczewa o działalności Oddziału za okres od stycznia 1945 r. do lipca 1950 r., [w:] Региональные структуры ГУПВИ НКВД-МВД СССР 1941-1951. Отчетно - информачионные документы, ред. М.М. Загорулько, Т. 5, к. 2, Волгоград 2006, с. 645-665.

22 WBH CAW, Kolekcja akt rosyjskich, sygn. CAW VIII.800.20.160, Stan internowanych $i$ aresztowanych $w$ obozie $n r 503 w$ Kemerowie za 1946 r., k. 16-18; tamże, sygn. CAW VIII. 800.20.900, Zestawienie statystyczne o liczbie $i$ obywatelstwie internowanych $w$ obozie $n r 503$ 
W okresie istnienia obozu nr 503, czyli w latach 1945-1949, jednym z podstawowych problemów, z jakim się on zmagał, był kiepski stan kadry obozowej. Nie było to nic wyjątkowego w systemie GUPWI NKWD/MWD ZSRS, ponieważ, gdy większość łagrów powoływano do życia w 1945 r., proces naboru kadry był szybki i niestaranny. Poza tym na początku 1945 r. brakowało mężczyzn do pracy, bowiem większość z nich służyła na froncie i akurat wówczas walczyła o Berlin. Kadra obozów złożona więc była z osób starszych lub bardzo młodych oraz ludzi niezdolnych do służby frontowej itp. W toku dalszej historii obozu pojawiły się dwa podstawowe czynniki wpływające na zachowanie jego obsady. Było to nadużywanie alkoholu oraz złodziejstwo, przejawiające się głównie przywłaszczaniem części racji żywnościowych przeznaczonych dla jeńców i aresztowanych. Także praktykowano na szeroką skalę wykorzystanie pracy osadzonych dla własnych celów (oczywiście za darmo) lub nawet kierowanie ich do realizacji konkretnych zadań dla osób prywatnych, za co oczywiście inkasowano zapłatę do własnej kieszeni. Dodatkowo trzeba pamiętać, że rozkład dyscypliny mógł też wynikać z faktu, że komendant obozu Iwaszkin praktycznie cały czas chorował i był nieobecny w pracy, a zastępował go Goldenberg (potem usunięty dyscyplinarnie z pracy). Jednocześnie mimo że od 19 października 1946 r. do końca istnienia obozu władzę komendanta sprawował Pantieliej Andriejewicz Dieszin ${ }^{23}$, to z dyscypliną cały czas były bardzo poważne problemy. Na 919 osób, które w okresie istnienia obozu przewinęly się przez jego kadry, nałożono w sumie 432 kary, w tym 39 z nich stanęło przed trybunami wojennymi. W kwietniu 1948 r. sąd ten skazał zastępcę naczelnika podobozu nr 5 - majora Safiulina - za kradzież chleba i ubrań z podległych mu magazynów. Miesiąc później już na 15 lat skazano Saratotina - zastępcę naczelnika ds. finansów podobozu nr 4, który przywłaszczał sobie pieniądze z kasy obozowej. Ciekawy jest przypadek Biełoborołowa - zastępcy naczelnika ds. finansów podobozu nr 2, który w 1949 r. po defraudacji gotówki zbiegł tak skutecznie, że udało się go schwytać dopiero na Ukrainie. Sąd w jego sprawie był bezlitosny i skazał go na 10 lat pobytu w łagrze. Zastępca komendanta obozu nr 503 ds. zaopatrzenia Goldenberg za pijaństwo oraz roz-

w okresie 1-31 I 1947 r., 1-28 II 1947 r., 1-31 III 1947 r., k. 19, 32-33, 48-49; tamże, sygn. CAW VIII.800.20.901, Stan internowanych w obozie nr 503 za okres 1-31 VII 1947 r., k. 52; tamże, sygn. CAW VIII.800.20.902, Zestawienie statystyczne o liczbie $i$ obywatelstwie internowanych $w$ obozie nr 503 w okresie 25 X 1949 r. - 25 I 1950 r., 1-25 II 1949 r., 25 II-25 III 1949 r., k. 4, 16, 32.

${ }^{23}$ Pantieliej Andriejewicz Dieszin - ur. w 1896 roku w chutorze Brzóski w obwodzie biełogorodzkim. Odbył tylko trzyletnią edukację w szkole wiejskiej i z uwagi na trudną sytuację rodziną musiał podjąć pracę najpierw jako parobek, a potem na własnym gospodarstwie rolnym. Już w $1920 \mathrm{r}$. wstąpił do partii bolszewickiej, ale szybko został z niej usunięty za ochrzczenie swojego dziecka. Drugi raz do partii został przyjęty w 1929 r. Po ukończeniu kursu pracowników operacyjnych pracował w organach NKWD, m.in. w Kraju Ałtajskim. W latach 1941-1943 pracował w UNKWD obwodu nowosybirskiego. Od 1943 r. zajmował się sprawą specprzesiedleńców w obwodzie kemerowskim. W latach 1946-1949 komendant obozu nr 503. М.А. Орлов, Началники управления кемеровского лагеря военнопленных и интернированных..., s. 138-141. 
kład dyscypliny został w początkach 1947 r. zwolniony z pracy. Podobnie było z zastępcą komendanta obozu ds. operacyjnych - kapitanem Zawołotinem. O jego usunięciu zadecydowało pijaństwo, kiepskie wyniki, intrygi i powodowanie sporów w pracy ${ }^{24}$.

Generalnie remedium na takie przypadki z jednej strony miały być kary, a z drugiej typowe dla systemu sowieckiego szkolenia partyjne i praca wychowawcza. Ostatecznie wszystkie te metody okazały się mało skuteczne i nadużycia cały czas miały miejsce ${ }^{25}$.

\section{Obóz nr 503. Warunki życia i pracy}

Opisywanie życia i pracy internowanych cywilów musi zawierać, obok dokumentów sprawozdawczych NKWD/MWD, jeszcze jeden komponent, bez którego odtworzony obraz byłby z gruntu fałszywy. Trzeba koniecznie sięgnąć po nieliczne zachowane wspomnienia osób, które trafiły do obozu $\mathrm{nr} 503$ i po powrocie opisały swój pobyt w tym łagrze ${ }^{26}$.

Czynnikiem mającym olbrzymi wpływ na życie osób deportowanych do Kemerowa był transport do obozu. Aresztowani byli przewożeni koleją na olbrzymie odległości i to w skrajnie trudnych warunkach. Wagony towarowe nie były przystosowane do transportu ludzi, którzy najczęściej siedzieli na podłodze w strasznym ścisku. Posiadamy dosyć precyzyjne informacje o transporcie aresztowanych, który wyruszył z Bytomia 3 kwietnia 1945 r., by pod koniec miesiąca (26 kwietnia) dotrzeć na miejsce. Obsługa eszelonu dopuściła się wówczas olbrzymich nadużyć w stosunku do przewożonych. Przede wszystkim systematycznie, co widzieli przez zakratowane okienka wagonów transportowani, na postojach

${ }^{24}$ WBH CAW, Kolekcja akt rosyjskich, sygn. CAW VIII.800.20.160., Sprawozdanie z działalności obozów nr 503, 525 oraz batalionu roboczego 1104 kierowane przez MWD obwodu Kemerowskiego do Naczelnika GUPWI MWD ZSRS generała lejtnanta Pietrowa, Kemerowo 8 II 1950 r., k. $50-94$.

${ }^{25}$ O skali nadużyć ze strony kierownictwa obozów świadczy fakt, że w latach 1943-1949 na terenie Syberii usunięto z powodów dyscyplinarnych naczelników obozów nr 93 (obwód tiumeński), 503, 525, 526 (obwód kemerowski) 36, 511 (Kraj Ałtajski) i większość ich zastępców. Także szef struktur GUPWI NKWD/MWD na obwód kemerowski stracił w ten sposób stanowisko. Za zabójstwo człowieka na pięć lat łagru został skazany zastępca naczelnika podobozu nr 4 obozu 503. А. Долголюк, Н.М. Маркдорф, Военнопленные в Сибири 1943-1955 г2. Историческое исследование и документальные материаль, часть I, Новосибирск 2014, с. 105-106.

${ }^{26}$ Kapitalnym źródłem informacji o obozie w Kemerowie są wspomnienia mieszkańca Krasowów (obecnie dzielnica Mysłowic) Ludwika Klimczoka „Internowanie 1945-1947”. Dokument ten ma przynajmniej dwie istotne cechy. Jest dosyć obszerny (kilkadziesiąt stron tekstu formatu A5) $\mathrm{i}$ - co najważniejsze - został napisany zaraz po powrocie $\mathrm{z}$ łagru, pod koniec lat 40 . XX w., a następnie ukryty w skrytce. Dopiero w 2013 r. zostały odnaleziony i wydany drukiem. Zob. L. Klimczok, Internowanie 1945-1947, [w:] „Wywieziono nas bydlęcymi wagonami”. Relacje deportowanych z Górnego Śląska do Związk Sowieckiego w 1945 roku, wybór i opracowanie S. Rosenbaum, D. Węgrzyn, Katowice 2015, s. 46-65. 
sprzedawano produkty żywnościowe z zaopatrzenia transportu i w zamian za to kupowano wódkę. Co dwa dni wydzielano dla aresztowanych po ćwierć litra kaszy na obiad, a rano wydawano porcje 300 g chleba jako wyżywienie na cały dzień. W czasie 24-dniowego transportu tylko dwa razy wydzielono gorącą wodę. Reakcją na krzyki głodnych i spragnionych, dobiegające z wagonów, były strzały oddane ze strony pijanych strażników. Padły ofiary śmiertelne. Wedle obliczeń przewożonych, zapewne niepełnych, w wagonach zmarło ponad 130 osób. Gdy eszelon dotarł na miejsce, obraz ludzi przeraźliwie brudnych (w czasie całej drogi na Wschód ani razu się nie myli, a tym bardziej kąpali), którzy „wypełźli” z wagonów, gdyż nie byli w stanie samodzielnie chodzić, wywarł wrażenie na przyjmujących transport funkcjonariuszach NKWD. Okazało się, że 450 osób, czyli około $1 / 3$ całego przewożonego kontyngentu, zostało zakwalifikowanych jako ciężko chorzy, z czego połowa tej grupy tak poważnie, że natychmiast wymagała umieszczenia w szpitalu. Władze obozu nr 503 szacowały, że odsetek chorych i osłabionych wśród przybyłych do łagru jeńców i cywilów w 1945 r. sięgał nawet $87 \%$.

Trzeba zaznaczyć, że już na etapie transportu potencjał przewożonej grupy jako darmowej siły roboczej został zmarnowany. Na miejsce dotarli ludzie w olbrzymim stopniu osłabieni i chorzy, którzy w normalnych warunkach wymagali długiego okresu rekonwalescencji, co w realiach sowieckiego łagru było niemożliwe. Stąd wysoka śmiertelność tuż po przybyciu do obozu oraz duży odsetek osób, którzy nie nadawali się do pracy lub mogli być zatrudnieni jedynie przy pracach lekkich, a tym samym przynoszących obozowi skromny dochód. Tym też można tłumaczyć stosunkowo krótki pobyt w łagrze aresztowanych, których jako ,element ekonomicznie zbędny” zaczęto zwalniać do domów już w drugiej połowie 1945 r. $^{28}$

27 Tak wysoki odsetek chorych i osłabionych może budzić pewne wątpliwości. Można się zastanawiać, czy nie są to dane przeszacowane. Podawanie tak wysokich wskaźników mogło mieć na celu próbę usprawiedliwienia wysokiej śmiertelności w obozie notowanej w 1945 r. Władze obozowe zrzucały w tej sytuacji odpowiedzialność za dużą liczbę zgonów na fatalny transport, a nie bardzo zły stan infrastruktury obozowej, niegotowej do przyjęcia tak dużej grupy jeńców i cywilów. Hipoteza ta jest trudna do udowodnienia, zwłaszcza, że relacje świadków potwierdzają koszmarne warunki panujące w eszelonach jadących do Kemerowa. WBH CAW, Kolekcja akt rosyjskich, sygn. CAW VIII.800.20.160, Sprawozdanie z działalności obozów nr 503, 525 oraz batalionu roboczego 1104 kierowane przez MWD obwodu Kemerowskiego do Naczelnika GUPWI MWD ZSRS generała lejtnanta Pietrowa, Kemerowo 8 II 1950 r., k. 50-94.

${ }^{28}$ O olbrzymiej skali tego zjawiska świadczy analiza akt Sądu Grodzkiego w Chorzowie, który m.in. w drodze postępowania „uznania za zmarłego” (ZG) w oparciu o relacje świadków ustalał czas i miejsce zgonu deportowanych. W spuściźnie aktowej tego sądu zachowało się 20 spraw osób, które zmarły w drodze do obozu w Kemerowie, w samym łagrze i podczas powrotu do domu. Ponad połowa zgonów przypada na transport do obozu, a do tego trzeba doliczyć jeszcze kilka śmierci osób osłabionych, którzy zmarli tu po przybyciu na miejsce. AIPN Ka, Sąd Grodzki Chorzów, sygn. 60/47, 480/47, 643/47, 847/47, 1073/47, 1167/47, 1221/47, 151/48, 278/48, 995/48, 225/49, Akta spraw uznania za zmartego $(Z G)$. 
Tezę o olbrzymim wpływie warunków transportu na śmiertelność w obozie nr 503 potwierdza statystyka zgonów w tym łagrze. W przypadku jeńców trzeba również pamiętać, że część z nich już na etapie punktów zbornych przy poszczególnych frontach Armii Czerwonej była w kiepskim stanie fizycznym, co wynikało z faktu, że dostali się do niewoli w efekcie walk frontowych. Część z transportowanych na Wschód była ranna. Oto tabela ze statystyką zgonów w obozie.

Tabela 2

\begin{tabular}{||c|c|c|c|c|c|}
\hline Rok & $\begin{array}{c}\text { Liczba osób, } \\
\text { które przeszły } \\
\text { przez obóz }\end{array}$ & $\begin{array}{c}\text { Średni stan } \\
\text { osobowy } \\
\text { obozu }\end{array}$ & Zmarło & $\begin{array}{c}\text { \% zmarłych } \\
\text { spośród tych, } \\
\text { którzy przeszli } \\
\text { przez obóz }\end{array}$ & $\begin{array}{c}\text { \% zmarłych } \\
\text { spośród śred- } \\
\text { niego stanu } \\
\text { obozu }\end{array}$ \\
\hline 1945 & 19053 & 7489 & 1904 & 10,0 & 25,4 \\
\hline 1946 & 14263 & 9086 & 491 & 3,4 & 5,4 \\
\hline 1947 & 12919 & 7520 & 162 & 1,3 & 2,2 \\
\hline 1948 & 13422 & 10251 & 62 & 0,5 & 0,6 \\
\hline 1949 & 7605 & 5293 & 13 & 0,2 & 0,2 \\
\hline
\end{tabular}

Źródło: М.А. Орлов, Кемеровский лагерь военнопленных и интернированых № 503 ..., с. 249.

Bardzo wysoką śmiertelność osadzonych w obozie nr 503 w 1945 r. nie tylko thumaczy się fatalnym stanem fizycznym kontyngentu „dostarczonego" do łagru. Poważnym problemem była infrastruktura obozowa, a właściwie jej brak. We wszystkich podobozach panowała olbrzymia ciasnota, a w podobozach $\mathrm{nr} 2$ i 4 zaistniała konieczność umieszczenia przybyłych w namiotach, całkowicie nieodpowiednich do syberyjskich warunków atmosferycznych. Na jednego osadzonego przypadał jeden metr kwadratowy powierzchni mieszkalnej. Brakowało łaźni, stołówki, suszarni i pralni. Wbrew przepisom pomieszczenia dla chorych lokowano w barakach mieszkalnych. Jeńcy i internowani najczęściej mieszkali w barakach - ziemiankach. Ich zaletą było utrzymywanie ciepła w zimie, ale wadą brak naturalnego oświetlenia, wilgoć, bród i wszechobecne wszy. Spano na piętrowych pryczach zbitych ze świeżych desek, bez żadnych sienników. Na zimę otrzymywano kożuchy, co pozwalało się okryć w czasie snu. Chorzy byli izolowani w osobnych pomieszczeniach, ale w 1945 r. brakowało nawet podstawowych leków i proces leczenia sprowadzał się najczęściej do zapewnienia lepszego wyżywienia oraz ogrzania pomieszczenia ${ }^{29}$.

${ }^{29}$ Wspomnienia deportowanych do obozu $\mathrm{nr}$ 503: Pawła Jamrożego, Jana Toborka i Ludwika Klimczoka, [w:] „Wywieziono nas bydlęcymi wagonami”..., s. 38-65. 
Na obiad wydawano tzw. cienki kapuśniak, suchary oraz kostkę cukru. Niejednokrotnie był to jedyny posiłek w ciągu dnia. Do picia wydawano gorącą wodę. Należy podkreślić, że racje żywnościowe miały się nijak do bardzo precyzyjnych norm wyżywienia jeńców i internowanych. Oczywiście wartość kaloryczna podawanych posiłków była skrajnie zaniżona w stosunku do normatywów NKWD/MWD ${ }^{30}$. Stosunek załogi poszczególnych podobozów do łagierników był najczęściej neutralny. Notowano wypadki, że zony obozowe były pozostawiane bez dozoru. Wynikało to z przekonania, że i tak ucieczka z obszarów Syberii była mało realna ${ }^{31}$. Co ciekawe, negatywny stosunek do osadzonych (określanych jako „faszystów”) przejawiała okoliczna ludność, choć trzeba pamiętać, że mieszkańcy tych terenów nie doświadczyli niemieckiej okupacji. Okoliczna ludność traktowała cały kontyngent obozowy jako „Niemców”, ewentualnie „Japończyków”, i nie miała pojęcia, że wśród nich mogli znaleźć się Polacy czy też Czesi ${ }^{32}$.

Stosunek mieszkańców Syberii do jeńców i internowanych jest o tyle ciekawy, że zupełnie inaczej wyglądała sytuacja na obszarach, gdzie rzeczywiście dotarły wojska III Rzeszy i poczyniły nawet olbrzymie szkody - np. na terenach Ukrainy czy też Białorusi. Tam otoczenie obozów raczej patrzyło na jeńców i internowa-

${ }^{30}$ Praktycznie w czasie ich pobytu w obozie obowiązywała norma wyżywienia określona rozkazem NKWD nr 00540 z 19 V 1945 r. Według niej każdy osadzony w łagrze miał dziennie otrzymywać m.in. $600 \mathrm{~g}$ chleba żytniego, $90 \mathrm{~g}$ kaszy, $30 \mathrm{~g}$ mięsa, $600 \mathrm{~g}$ kartofli oraz $100 \mathrm{~g}$ ryby. Trzeba pamiętać, że znaczna część tych produktów była przywłaszczana przez załogę obozu, na co potwierdzeniem są liczne kary dyscyplinarne, ale i wyroki przed trybunałem wojennym. Pełną normę wyżywienia zob. w: Русский архив: Великая Отечественная, Т. 24 (13), Иностранные военнопленные второй мировой войны в СССР, под. ред. А.В. Золоторева, Москва 1996, c. $188-190$.

${ }^{31}$ Rzeczywiście nie udało się nikomu skutecznie uciec z obozu nr 503. W 1945 roku uciekło co prawda 41 osób, ale $40 \mathrm{z}$ nich schwytano, a jedna osoba zginęła podczas pościgu. W kolejnych latach również były próby ucieczek: 1946 - 25, 1947 - 12, 1948 - 3. Wszyscy uciekinierzy zostali schwytani, przy czym 5 osób zabito podczas pościgu. Sumaryczne sprawozdanie naczelnika Zarządu Kemerowskiego obozu nr 503 w obwodzie Kemerowo majora Dieszina z działalności za okres od V 1945 roku do listopada 1949 roku, Kemerowo 31 XII 1949, [w:] Региональные структуры ГУПВИ НКВД-МВД СССР 1941-1951..., с. 674.

${ }^{32}$ Przed rokiem $1941 \mathrm{w}$ wielu miejscach uczono w szkołach języka niemieckiego, a obraz Niemców był na ogół pozytywny. Dość radykalna zmiana podejścia do Niemców wśród mieszkańców Syberii nastąpiła w okresie Wielkiej Wojny Ojczyźnianej. W propagandzie jaką kierowano do obywateli ZSRS utrwalano obraz „Niemca - faszysty”, odpowiedzialnego zbiorowo za wszelkie krzywdy jakie spotkały ZSRS. Rozsadnikiem agresji wobec niemieckich jeńców i cywilów mogli być mieszkańcy zachodnich rejonów ZSRS ewakuowani w czasie wojny na obszary Syberii, lub też żołnierze odesłani z frontu na rekonwalescencję. Po wojnie bardzo powoli w działaniach propagandowych zaczął się pojawiać proces oddzielania „,narodu niemieckiego” od „,aszyzmu niemieckiego" jako zjawisk nie do końca się pokrywających. Długo jednak propaganda czasu wojny miała decydujący wpływ na mieszkańców obszarów syberyjskich. А. Долголюк, Н. М. Маркдорф, Военнопленные в Сибири 1943-1955 г2..., с. 215-235. 
nych jako na współtowarzyszy wspólnej niedoli, gdyż okoliczna ludność często na równi z nimi cierpiała głód i niedolę wynikające ze zniszczeń wojennych ${ }^{33}$.

Kolejnym czynnikiem warunkującym życie w obozie nr 503 była wysoka zachorowalność kontyngentu, zwłaszcza notowana w latach 1945-1947. Wynikała wprost z kiepskich warunków lokalowych, fatalnych warunków fito-sanitarnych, braku podstawowej opieki medycznej i szczepień ochronnych, niskich i ubogich pod względem kalorycznym racji żywnościowych oraz ciężkiej pracy w skrajnie trudnych syberyjskich warunkach. Co ważne, w sytuacji, gdy zwłaszcza w 1945 r. wypuszczano do domu tylko i wyłącznie osoby chore, pojawiło się zjawisko samookaleczeń oraz celowego zaniżania stanu zdrowia. Generalnie w latach 1945-1947 ok. 20-25\% spośród wszystkich osób osadzonych w obozie przebyło różnorakie choroby. Trzeba także pamiętać o dużym wpływie czynników natury psychologicznej na stan zdrowia osadzonych. Dzięki skutecznym działaniom propagandy III Rzeszy samo słowo „Sybir” wśród żołnierzy niemieckich i cywilów budziło przerażenie, a ludzie ci właśnie się tam znaleźli i często byli przekonani, że żywi stamtąd do domów nie wrócą. Równie złe skojarzenia mieli Polacy - znający z historii przypadki zsyłki w ten rejon Rosji. Podjęte przez załogę obozu środki zaradcze wydają się całkiem racjonalne, oczywiście jeżeli weźmiemy pod uwagę materiały sprawozdawcze, a nie realizację założonych celów w praktyce. Generalnie wprowadzono zasadę sprawdzania stanu zdrowia jeńców i internowanych dwa razy w miesiącu przez komisję lekarską, co pozwalało zidentyfikować osoby chore, ale i odpowiednio ustalić stopień zdolności do pracy tych osób w oparciu o ich kondycję fizyczną. W okresie przygotowań do zimy 1945/1946 r. skontrolowano wszystkie pomieszczenia, by usunąć niedociągnięcia, a chorych oddzielono od zdrowych. Zwrócono także uwagę na jakość wydawanych posiłków i ich kaloryczność. Uzupełniono też braki w ubraniach i obuwiu.

Zupełnie inny obraz wyłania się ze wspomnień Ludwika Klimczoka, który 20 grudnia 1945 r., czyli już dawno po podjęciu owych „kroków naprawczych”, trafił do lazaretu głównego obozu nr 503. Opis pobytu w tym lazarecie jest przerażający i wart zacytowania:

W pokojach wyglądających jak chlew leżeli razem chorzy na choroby zakaźne, np. na czerwonkę, biegunkę, tyfus, różę, flegmonę itp. Codziennie umierało tam do siedmiu osób. Szpital był zawszony i zapluskwiony. Nocą nie miałem spokoju i nie dało się spać. Nogi umieszczono mi w takich ramkach z drewna i podnoszono do góry, robiono okłady z brą-

${ }^{33}$ Generalnie o pozytywnym nastawieniu (lub neutralnym) wspomina deportowany do batalionu roboczego w Ratomce w okolicach Mińska na Białorusi mieszkaniec podgliwickiej Ostropy Ignacy Kowol. Zob. Relacja Ignacego Kowola, [w:] E.H. Borkowska, U. Dyklong, A. Jonderko, „Mieli wrócić za czternaście dni”. Mieszkańcy Ostropy w obozach pracy przymusowej w Związu Sowieckim (1945-1949), Katowice-Gliwice 2014, s. 101-112. 
zowego specyfiku. Wszystkimi porami stóp wypływała ropa. Ręce smarowano różnymi maściami. Gorączka podnosiła się do 40 stopni. Przez kilka dni nic nie jadłem, smakowało mi tylko palenie i Bogu dzięki wytrzymałem. [...] Sienników nie było, tylko gołe deski albo worki z trocinami. Miałem ogromne bóle, bo wrzody stale mi nacinali, ale musiałem wszystko wytrzymać. Gdy rankiem wołano na śniadanie, codziennie miałam za sąsiadów zmarłego z mojej prawej strony i zmarłego z lewej ${ }^{34}$.

Generalnie należy stwierdzić, że aż trzy lata zajęło władzom obozowym opanowanie sytuacji jeśli chodzi o zachorowalność osadzonych. Nie jesteśmy w stanie stwierdzić w jakim stopniu osiągnięto to poprzez rzeczywiste działania naprawcze na wielu polach, a w jakim wynikało to z faktu ,pozbycia się" w wyniku repatriacji osób słabych i chorych. W obozie pozostali ludzie, którzy przystosowali się do skrajnie trudnych warunków syberyjskich. Poznali też miejscową faunę i florę oraz podstawowe tajniki miejscowej medycyny ludowej. Niewątpliwie opieka medyczna uległa poprawie. Należy zwrócić uwagę na fakt, że personel medyczny, który był rekrutowany spośród jeńców i internowanych, stanowił nawet do 50\% całej obsady lekarzy i średniego personelu medycznego, potrzebował czasu, by poznać i co najważniejsze wypracować skuteczne metody leczenia chorób, które występowały na Syberii, a z którymi dotychczas nie miał do czynienia. Także zaludnienie obozu zmniejszyło się, a co za tym idzie ciasnota już nie była takim problemem. Powstała lub została uzupełniona cała infrastruktura (stołówki, łaźnie, komory do dezynfekcji, ambulatoria itp.). Pojawiły się też tzw. komanda ozdrowieńcze, do których kierowano rekonwalescentów. Ludzie po przebytych ciężkich chorobach mogli liczyć w nich na lepsze jakościowo pożywienie, lżejszą pracę i w miarę przyzwoite (jak na warunki obozowe) pomieszczenia ${ }^{35}$.

Troska o zdrowie chorych nie tylko wynikała z pobudek humanitarnych, ale może i w większym stopniu ze względów ekonomicznych. Tylko zdrowi jeńcy i aresztowani mogli pracować i przynosić obozowi dochód. Podstawowe dane odnośnie pracy osadzonych w obozie nr 503 prezentuje poniższa tabela:

${ }^{34}$ L. Klimczok, Internowanie 1945-1947, [w:] „Wywieziono nas bydlęcymi wagonami”..., s. $57-58$.

35 Jeden z jeńców, a zarazem syberyjskich lekarzy obozowych tak wspominał swoją pracę: „W pierwszą zimę pobytu w obozie spotkaliśmy się z chorobami, o których wiedzieliśmy tylko z podręczników. Na diagnostykę i leczenie było potrzebne niemało środków i wysiłków. Fizyczny i stan duchowy Niemców charakteryzował się wyjątkową obojętnością i apatią do wszystkiego wokoło. Właśnie z tym stanem przypadło nam walczyć przede wszystkim [podkreślenie autora]. Nie należy kwestionować faktu, że dla pacjentów robiliśmy wszystko, co możliwe, co było w naszych siłach, bez względu nas to, kim byli chorzy - Niemcy, Rumuni albo Japończycy”. Cyt. za: H.M. Mapкдорф, Медико-санитарное обеспечение иностранных военнопленных и интернированных в лагерях и рабочих батальонах Западной Сибири: 1943-1950 г2., „Вестник Омского университета" 2012, № 3 (65), с. 142-146. 
Tabela 3

\begin{tabular}{|c|c|c|c|c|c|}
\hline & \multicolumn{5}{|c|}{ Lata } \\
\hline & 1945 & 1946 & 1947 & 1948 & 1949 \\
\hline Liczebność obozu & 7489 & 9086 & 7520 & 10251 & 5293 \\
\hline Siły robocze & 6197 & 7117 & 5894 & 8975 & 4909 \\
\hline \% zdolnych do pracy & 82,7 & 78,3 & 78,3 & 87,4 & 92,7 \\
\hline $\begin{array}{l}\text { Liczba pracujących na zakon- } \\
\text { traktowanych stanowiskach }\end{array}$ & 4436 & 5580 & 4686 & 7549 & 4502 \\
\hline $\begin{array}{l}\text { \% wychodzących do pracy } \\
\text { spośród sił roboczych }\end{array}$ & 71,5 & 78,4 & 79,5 & 84,1 & 91,7 \\
\hline \% wypełniających normy & 18,7 & 50,5 & 61,2 & 68,3 & 70,0 \\
\hline
\end{tabular}

Źródło: WBH CAW, Kolekcja akt rosyjskich, sygn. CAW VIII.800.20.160, Sprawozdanie z dziatalności obozów nr 503, 525 oraz batalionu roboczego 1104 kierowane przez MWD obwodu kemerowskiego do Naczelnika GUPWI MWD ZSRS generata lejtnanta Pietrowa, Kemerowo 8 II 1950 r., k. 50-94.

Tabela potwierdza, że duży wpływ na ekonomikę i produktywność obozu miał stan fizyczny jeńców i internowanych. Spośród osadzonych w obozie nr 503, do pracy zdolnych było od $78 \%$ do $92 \%$ tam przetrzymywanych. Ale równocześnie nawet ci, których kwalifikowano jako osoby przeznaczone do wysłania do pracy, nie wychodzili do niej w komplecie. Szczególnie to zjawisko było widoczne w 1945 r., kiedy $30 \%$ zdolnych do pracy przebywało w obozie nie pracując na zewnątrz i nie przynosząc tym samym zarobku, a równocześnie generując koszty (wyżywienie, ubrania, utrzymanie itp.). Zjawisko to można thumaczyć tym, że władze obozowe zawyżały kategorie zdolności do zatrudnienia, kwalifikując do niego osoby, które potem nie były w stanie takiej pracy podjąć z uwagi na stan zdrowia. Do tego dochodził dosyć typowy dla systemu sowieckiego chaos przejawiający się brakiem komunikacji na linii obóz - zakłady zatrudniające osadzonych. Zdarzały się bowiem okresy, gdy nie było podpisanych stosownych umów i tym samym nie było zatrudnienia dla jeńców i aresztowanych, co było paradoksem w sytuacji olbrzymich strat poniesionych przez ZSRS w wyniku wojny i deficytu siły roboczej. Najbardziej jednak rzuca się w oczy katastrofalnie niska wydajność pracy. W 1945 r. tylko około 18\% kierowanych do zakładów wypełniało normę ustalaną zazwyczaj na poziomie cywilnego pracownika danego przedsiębiorstwa. W kolejnym roku było to ok. 50\% wykonania normy, by w latach 1948-1949 osiągnąć poziom $70 \%$. Na tak niską wydajność, zwłaszcza w pierwszym okresie 
lat 1945-1946, złożyło się kilka czynników. Jeńcy i internowani nastawieni byli wówczas na szybki powrót do domów i nie byli motywowani do pracy systemem nagród (zwiększenie norm wyżywienia, obietnice wcześniejszego odesłania do domu przodowników pracy itp.). Kluczową rolę odgrywał też surowy klimat syberyjski. Mieszkańcy centralnej i zachodniej Europy nie byli w stanie przyzwyczaić się do upałów w okresie lata (wraz z olbrzymią masą owadów i insektów), a w zimie do mrozu sięgającego minus $50^{\circ} \mathrm{C}$, połączonego zazwyczaj z silnym wiatrem. Nie zawsze trzymano się zasady nie wysyłania do pracy na wolnym powietrzu osadzonych $\mathrm{w}$ okresie najniższych temperatur oraz zaniedbywano sprawę organizacji specjalnych punktów, gdzie mogliby się wówczas ogrzać. Jak się okazało, zwykłe ognisko w sytuacji silnego wiatru nie było wystarczającym remedium na szybkie wychładzanie się organizmów. Władze obozowe starały się wysłać do pracy maksymalnie dużą grupę łagierników nie oglądając się na ich stan fizyczny, a w przypadku osób osłabionych - nie organizując im odrębnych stanowisk ze zmniejszoną normą i zatrudnieniem pod dachem. Generalnie bodaj największym mankamentem była słaba, a często wręcz brak jakiejkolwiek organizacji pracy. Paweł Jamroży (aresztowany w Mysłowicach) pracował w cegielniach, w kopalniach, w kołchozie oraz w warsztatach ${ }^{36}$. Ewidentnie cywilów posiadających niejednokrotnie wysokie kwalifikacje (zwłaszcza było to widoczne wśród robotników aresztowanych na terenie Górnego Śląska) kierowano do zakładów przemysłowych, realizując tym samym doraźne zapotrzebowanie na siłę roboczą. W realiach częstych zmian dyslokacji „frontu pracy” nie było czasu, by nabyć doświadczenia potrzebnego do sprawnej realizacji nałożonych zadań. Przedsiębiorstwa zatrudniające kontyngent obozu zlecały im najczęściej najcięższe zadania oparte na pracy fizycznej bez użycia maszyn i urządzeń, a zarazem słabo płatne. Nie kwapiły się też do zapewnienia odzieży ochronnej czy - w przypadku dużej odległości od obozu - transportu. Nie było więc w 1945 r. wyjątkiem, że jeńcy szli na miejsce zatrudnienia nawet 10 kilometrów i równocześnie pozostawali bez posiłku przez 10-12 godzin. Maksymalna eksploatacja kontyngentu obozowego przejawiała się wydłużaniem czasu pracy do 12 godzin oraz zapewnianiem tylko jednego dnia wypoczynku w tygodniu (najczęściej była to niedziela) ${ }^{37}$.

Mimo że w latach 1945-1946 ewidentnie władze obozu miały olbrzymie problemy z wykorzystaniem posiadanej siły roboczej, która dodatkowo cechowała się niską wydajnością wynikającą głównie z kiepskich warunków życia oraz słabej kondycji fizycznej, to jeńcy i internowani odegrali dużą rolę w gospodarce Syberii. W czasie Wielkiej Wojny Ojczyźnianej region ten stracił co dziesiątego mężczyznę, a znaczna część mieszkańców służyła w Armii Czerwonej i przez

${ }^{36}$ Wspomnienia deportowanego do obozu nr 503 Pawła Jamrożego, [w:] „Wywieziono nas bydlęcymi wagonami"..., s. 38-39.

37 Wspomnienia deportowanego do obozu nr 503 Jana Toborka, [w:] „Wywieziono nas bydlęcymi wagonami"..., s. 40-45. 
długi czas pozostawała poza domem oraz swym zakładem pracy. Lukę tę wypełnili jeńcy i internowani. W latach 1943-1949 w rejon Syberii nadpłynęło ich 235 tys. Już sama ich masa miała olbrzymi wpływ na życie regionu, zwłaszcza w okresie planu gospodarczego 1946-1950, w którym nastąpiła komasacja działań inwestycyjnych. Trudno znaleźć jakiś wielki kombinat przemysłowy na Syberii, wielką budowę tego okresu (zwłaszcza linie kolejowe np. linia Tajszet-Brack), przy których wznoszeniu nie brali udziału jeńcy i internowani. Przy robotach leśnych stanowili oni nawet $60-70 \%$ obsady. Pewnego symbolicznego znaczenia nabiera fakt, że to ich rękami wzniesiono budynku filii Akademii Nauk w Nowosybirsku. Właśnie budownictwo (a szczególnie praca w cegielniach) było tą dziedziną gospodarki syberyjskiej, do której chętnie kierowano aresztowanych mieszkańców Europy Środkowo-Wschodniej ${ }^{38}$.

Zamykając kwestie ekonomiczne związane z funkcjonowaniem obozu nr 503 trzeba podkreślić jeden podstawowy fakt. W latach 1945-1947, czyli przez większą część swego istnienia, był on deficytowy, to znaczy przychody nie równoważyły wydatków i jego funkcjonowanie wymagało dotacji ze strony NKWD/MWD. Dopiero rok 1948 przyniósł zarobek. Z kolei rok 1949 to czas likwidacji obozu (masowa repatriacja ruszyła w lipcu 1949 r.), a tym samym szybkiego zmniejszania się kontyngentu osób w nim osadzonego. Wypracowany zysk z tego okresu nie mógł już być znaczący. Poza tym globalny zysk obozu z lat 1948-1949 wynikał nie tyle $\mathrm{z}$ dobrej organizacji pracy i właściwego zarządzania całym łagrem, a raczej z „sukcesów ekonomicznych” niektórych jego podobozów. W 1948 r. podobóz nr 2 nadal był deficytowy, podczas gdy podobóz nr 3 wypracowywał aż $33 \%$ globalnego zysku obozu ${ }^{39}$.

Sferą, która całkowicie umyka w badaniach nad sowieckimi łagrami systemu GUPWI NKWD/MWD, jest codzienność obozowa. Sowieckie materiały sprawozdawcze są w tym względzie bezużytecznie, gdyż nie rejestrowały tego typu zjawisk. Wbrew pozorom także zachowane wspomnienia nie są bogate w sferę informacyjną jeśli chodzi o ten aspekt historii obozu. W zachowanych źródłach dominuje odtworzenie warunków zamieszkania, kwestie wyżywienia, opieki medycznej, śmierci oraz ciężkiej pracy. Całkowicie są pomijane stosunki międzyludzkie, podczas gdy w nowszych badaniach wskazuje się, że w obozie tworzył się swoisty mikroświat $\mathrm{z}$ wyraźną hierarchią. Procesy adaptacyjne przebiegały bardzo powoli, a stan traumy i strachu w związku ze znalezieniem się na osławionej Syberii trwał długo. Wiele zjawisk kumulowało się w związku z olbrzy-

${ }^{38}$ Szerzej o udziale jeńców i internowanych w powojennej syberyjskiej ekonomice zob. А. Долголюк, Н.М. Маркдорф, Иностранные военнопленные и интернированные в сибирской экономике (1944-1956 г2.), „Иркутский историко-экономический ежегодник” 2014, с. 42-52.

${ }^{39}$ WBH CAW, Kolekcja akt rosyjskich, sygn. CAW VIII.800.20.160, Sprawozdanie z działalności obozów nr 503, 525 oraz batalionu roboczego 1104 kierowane przez MWD obwodu Kemerowskiego do Naczelnika GUPWI MWD ZSRS generata lejtnanta Pietrowa, Kemerowo 8 II 1950 r., k. 50-94. 
mią ciasnotą panującą w pomieszczeniach, w których przebywali łagiernicy. Nie mamy żadnych informacji na temat tego jak układały się stosunki między cywilami a jeńcami przebywającymi w tym samym podobozie. Co prawda, ich zony był wydzielone, ale do kontaktów musiało siłą rzeczy dochodzić. Wśród cywilów pojawiły się kobiety, których obecność w zdominowanym przez mężczyzn świecie obozowym miała niebagatelne znaczenie. Wspomnienia milczą o osobach, które nie poradziły sobie psychicznie w tych skrajnych warunkach i przeżyły załamanie nerwowe. Sfera religijna jest zaznaczana jedynie krótką konstatacją, że mimo faktu, że w obozach byli duchowni (jeńcy kapelani wojskowi), to o odprawianiu mszy św. nie było mowy, a wiara mogła być jedynie werbalizowana przez modlitwę indywidulaną. Materialną pamiątką tej sfery życia obozowego są różańce wykonywane najczęściej z drutu. Obok religii źródłem nadziei dla internowanych cywilów mogły być listy do i od rodzin. Choć rozkaz MWD nr 00574 z 21 czerwca 1946 r. wprowadzał taką możliwość, w obozie w Kemerowie była to niezwykła rzadkość. Mogło to być przyczyną frustracji dla internowanych w sytuacji, gdy jeńcy najczęściej korzystali z tego prawa otrzymując korespondencję ${ }^{40}$.

Na koniec można się zastanowić, czy istniała jakaś strategia dająca większe szanse na przeżycie $\mathrm{w}$ tych skrajnych warunkach, a potem na powrót do domu. Deportowani podkreślają dużą rolę szczęścia (nazywanego najczęściej „Opatrznością Bożą"). Rozmowy z nielicznymi świadkami pobytu w sowieckich łagrach wskazują, że bardzo często w pierwszej kolejności umierali ci, którzy po przybyciu do obozu byli nadaktywni, którzy podkreślali, że z pewnością obóz przeżyją. Wraz z upływem czasu ich energia słabła, a pojawiała się apatia, a potem załamanie i w konsekwencji choroba i śmierć. O wiele lepszą metodą okazało się zredukowanie funkcji organizmu do minimum i nastawienie się na przeżycie do następnego dnia. Nie była to apatia, ale swoista metoda „małych kroków” z wyznaczonym celem - powrotem do domu ${ }^{41}$.

${ }^{40}$ Rozkaz miał na celu dać możliwość wynagradzania dobrze pracujących internowanych poprzez przywilej pisania listów do domów. Oczywiście korespondencja była cenzurowana. Należy dodać, że niemieccy jeńcy wojenni prawo do pisania i otrzymywania listów otrzymali kilka miesięcy wcześniej, bo 5 IX 1945 r. Istnieje niejasność odnośnie kwestii prawa do korespondencji wśród internowanych - aresztowanych, którzy w odróżnieniu od zmobilizowanych do batalionów roboczych najczęściej byli obejmowani przepisami analogicznym do tych obowiązujących jeńców, z którymi zresztą bardzo często przebywali w jednym obozie, choć w wydzielonych zonach. Rozkaz MWD nr 00574 z 21 VI 1946 r. o zezwoleniu na korespondencje z rodzinami dla internowanych osadzonych $w$ batalionach roboczych, [w:] В.Б. Конасов, Военнопленные и интернированныле граждане Германии: путь на родину из СССР (1940-1950-е годы). Документы, факты, комментарии, Москва 2001, с. 24, 267-268.

${ }^{41}$ Odnośnie strategii przeżycia w obozie takie wnioski płyną z rozmowy autora z deportowanymi: Alfredem Kubicą z Orzesza i Janem Kurzydymem z Rybnika. W odniesieniu do obszarów Syberii o zagadnieniach związanych z codziennością obozową i relacjami pomiędzy osadzonymi w łagrze a okoliczną ludnością szerzej zob. w: А. Долголюк, Н.М. Маркдорф, Иностранные военнопленные и интернированные в Сибири (1943-1950), Москва 2016, с. 240-263. 
Ostatnim istotnym elementem opisu historii obozu nr 503 jest kwestia repatriacji tych, którzy przeżyli. Niestety, zachowane dokumenty nie wyszczególniają w grupie repatriantów poszczególnych kategorii więźniów (cywilów czy jeńców wojennych). W pierwszych trzech latach funkcjonowania obozu (1945-1947) grupy odsyłanych do domów nie były duże i nie przekraczały trzech tys. osób rocznie. W 1945 r. było ich 2996, 1946 r. - 2380, a w 1947 r. - 2966 odesłanych. Większe wahania stanu osadzonych $\mathrm{w}$ obozie wynikały raczej z redystrybucji siły roboczej w ramach systemu GUPWI NKWD/MWD, niż z faktu zwalniania łagierników do domów. W przypadku wypuszczanych na wolność prawie zawsze obowiązywała zasada pozbywania się osób ekonomicznie zbędnych (chorych, osłabionych, inwalidów oraz kobiet w ciąży lub z małymi dziećmi). Większa partia wypuszczonych na wolność pojawiła się w 1948 r., kiedy to takich osób było już 5561. Ostatni etap likwidacji obozu ruszył 4 lipca 1949 r. Do września tamtego roku wypuszczono na wolność i odesłano transportami kolejowymi 7615 osób. Równolegle pracowała specjalna komisja likwidacyjna z komendantem Dieszinem na czele. W związku z likwidacją łagru pojawiła się także specjalna komisja z Moskwy, która dokonała lustracji wszystkich podobozów. Ponadto do września 1949 r. porządkowano sprawę kadry obozowej. O ile szeregowi pracownicy, a zwłaszcza obsługa techniczna (kucharki, magazynierzy itp.), byli zwalniani z pracy, to kadra zarządzająca prawie w całości została skierowania do dalszej pracy w organach MWD. W przypadku zwalnianych cywilów (oraz jeńców wojennych) obowiązywała zasada kierowania ich do krajów, z których pochodzili. Osoby uznane za Niemców trafiały do obozu nr 69 we Frankfurcie nad Odrą i tam dopiero odzyskiwały wolność. Osoby uznane za Polaków trafiały do obozu tranzytowego nr 284 w Brześciu nad Bugiem i systematycznie były przekazywane stronie polskiej. Niekiedy powodowało to zamieszanie w przypadku mieszkańców obszarów pogranicznych o skomplikowanej sytuacji narodowościowej. Duża grupa deportowanych z Górnego Śląska (mimo że obszar ten znajdował się w granicach Państwa Polskiego) uznawana za Niemców trafiała do Frankfurtu nad Odrą i dopiero z Zachodu wracała do domów ${ }^{42}$.

42 А.В. Бельков, М.А. Орлов, Иностранные военнопленные и интернированные как одна из волн принудительной миграции на территории Кемеровской области (1944-1950 гг.), Вестник Вятского государственного гуманитарного университета, № 4/215, c. 66-73; Sumaryczne sprawozdanie naczelnika Zarządu Kemerowskiego obozu nr 503 w obwodzie Kemerowo majora Dieszina z działalności za okres od V 1945 roku do listopada 1949 roku, Kemerowo 31 ХІІ 1949, [w:] Региональные структуры ГУПВИ НКВД-МВД СССР 1941-1951..., с. 668, 678-681. 


\section{Próba podsumowania}

Obóz nr 503 w Kemerowie należał do sieci łagrów systemu Głównego Zarządu ds. Jeńców Wojennych i Internowanych NKWD/MWD ZSRS. Wśród setek tego typu łagrów jego cechą szczególną było to, że należał do znacznie mniejszej grupy kilkunastu obozów, w których obok jeńców wojennych byli przetrzymywani aresztowani - internowani cywile z Europy Środkowo-Wschodniej. Wśród grupy ponad czterech tys. osób odesłanych do Kemerowa w 1945 r. znaczny odsetek stanowiły osoby aresztowane na Górnym Śląsku, na Pomorzu Nadwiślańskim oraz w Prusach Wschodnich. W ramach operacji NKWD „czyszczenia tyłów” Armii Czerwonej aresztowano szeroką grupę osób - od żołnierzy AK z jednej strony, po osoby związane z aparatem nazistowskim z drugiej. Analiza osób aresztowanych w ramach tej akcji na terenie Górnego Śląska wskazuje, że mieścili się oni raczej pośrodku tego przedziału ${ }^{43}$. Co prawda aresztowano żołnierzy AK w rejonie miasta Tychy, ale nie można powiedzieć, że funkcjonariusze NKWD rozpoznali i zatrzymali struktury konspiracji z czasów okupacji niemieckiej na Górnym Śląsku ${ }^{44}$. Jak widać sieć agenturalna i działania rozpoznawcze w wykonaniu sowieckiego aparatu represji wcale nie były aż tak skuteczne. Podobnie sytuacja wyglądała w przypadku gorliwych współpracowników III Rzeszy. Okazało się, że osoby aktywne w NSDAP, SA czy w administracji niemieckiej uciekły przed zbliżającym się frontem. W efekcie spośród aresztowanych spory odsetek stanowiły osoby należące do Niemieckiego Frontu Pracy (Deutsche Arbeitsfront, DAF), czyli ujednoliconych związków zawodowych, do których obowiązkowo należeli wszyscy pracobiorcy. Trudno taką organizację określić jako stricte nazistowską, choć oczywiście, jak wszystko w III Rzeszy, podlegała ona kontroli NSDAP ${ }^{45}$.

${ }^{43}$ Podstawą do formułowania takich wniosków jest prowadzona przez autora elektroniczna baza danych osób internowanych i aresztowanych na terenie Górnego Śląska w 1945 r. przez władze sowieckie i następnie deportowanych do sowieckich łagrów oraz batalionów pracy. Na dzień 3 V 2018 r. baza ta liczy 45100 nazwisk deportowanych, co stanowi ponad 95\% wszystkich wywiezionych przez władze ZSRS z tego rejonu.

${ }^{44}$ W. Schäffer, „Matka mi godała, że z Wilkowyj wywieźli 33 osoby”, [w:] „Niech świat pamięta o nas...". Losy osób deportowanych do ZSRS z terenu Górnego Śląska w 1945 r., pod red. K. Banaś, Katowice 2016, s. 27-78.

${ }^{45}$ Właśnie pod zarzutem przynależności do DAF został aresztowany i wywieziony do Kemerowa znany katowicki artysta plastyk Paweł Steller (1895-1974), absolwent Akademii Sztuk Pięknych w Warszawie, uczeń Władysława Skoczylasa, znany zwłaszcza ze swych drzeworytów, rysunków, linorytów oraz litografii. Podczas okupacji ukrywał się wraz z żoną w rejonie Beskidów współpracując z ruchem oporu. Po powrocie do Katowic otrzymał zlecenie zaprojektowania i nadzoru wykonania Pomnika Wdzięczności Armii Czerwonej, który został odsłonięty w Katowicach 27 II 1945 r. Wkrótce, bo 4 III 1945 r., został aresztowany przez NKWD i wywieziony do obozu w Kemerowie. Na miejscu zdobył przybory do rysowania i wykonał na skrawkach papieru około dwóch tys. ołówkowych portretów współwięźniów, strażników obozowych oraz okolicznej ludno- 
Oceniając pobyt aresztowanych w sowieckich łagrach można z pewnością stwierdzić, że zmarnowano ich potencjał ekonomiczny. W założeniach ludzie ci mieli pracować na potrzeby gospodarki sowieckiej odbudowując zniszczenia z okresu wojny. Okazuje się, że obóz kemerowski, gdzie w latach 1945-1946 stanowili większą grupę, nie był w stanie wygenerować zysku i wymagał dotacji z zewnątrz. Wynikało to z fatalnego sposobu organizacji transportów deportowanych do sowieckich łagrów, skrajnie trudnych warunków życia i pracy w obozach oraz nieudolnego zarządzaniu siłą roboczą ze strony władz obozowych i równie nieefektywnemu jej wykorzystaniu ze strony przedsiębiorstw sowieckich. Trudno też mówić, że aresztowanie tych ludzi i wywiezienie ich w głąb ZSRS zapewniło spokój na tyłach Armii Czerwonej i „oczyściło jej tyły”. Przynajmniej w przypadku terenów Górnego Śląska, gdzie posiadamy sporą wiedzę o personaliach aresztowanych i wywiezionych, trudno ich określić jako osoby niebezpieczne dla władz sowieckich. Raczej można powiedzieć o przypadkowości zatrzymań i maskowaniu względami politycznymi zwykłej branki siły roboczej, notabene zmarnowanej w realiach sowieckich łagrów. W jednym względzie pobyt w łagrze okazał się niezwykle „skuteczny”. Osoby, które przeżyły i powróciły z sowieckich łagrów praktycznie do końca swojego życia zmagały się z potworną traumą. Wielu z nich nie poradziło sobie z nią i popadło w alkoholizm oraz miało olbrzymie problemy z ułożeniem prawidłowych relacji rodzinnych. Szkody dotyczyły nie tylko sfery psychicznej, ale i fizycznej, gdyż powracali ludzie chorzy, których rekonwalescencja przebiegała powoli, a i tak okres pobytu w skrajnie trudnych warunkach łagrowych odcisnął piętno na ich zdrowiu w kolejnych latach życia.

Kamerowo, a raczej szerzej Syberia, stały się symbolem pracy przymusowej w ZSRS okresu końca wojny i po jej zakończeniu. Mimo że w tym rejonie ulokowano znacznie mniej cywilów z Europy Środkowo-Wschodniej niż np. w rejonie Donbasu na Ukrainie, to właśnie „Sybir” jest słowem kluczem do opisania tego niezwykle bolesnego dla wielu mieszkańców Europy wydarzenia.

ści. Zapłatą za owe rysunki była żywność, co pozwoliło mu przeżyć i w listopadzie 1946 r. wrócić do rodziny w Katowicach. S. Steller, Wspomnienia: „Mój ojciec”, [w:] Pawet Steller. życie i twórczość, część pierwsza: życie (1895-1974), pod red. A. Barnaś, Katowice 2006, s. 5-66; J. Golec, S. Bojda, Steller Pawet, „Słownik biograficzny ziemi cieszyńskiej”, t. 2, Cieszyn 1995, s. 218-219; WBH CAW, Kolekcja akt rosyjskich, sygn. CAW VIII.800.20.481, Spis Polaków, obywateli polskich, osadzonych w obozach obwodu Kemerowskiego, Kemerowo 15 VI 1945 r., k. 50. 
Dariusz Węrzyn

\title{
HISTORY OF NKVD 503 KEMEROVO CAMP WITH PARTICULAR RESEARCH ON IMPRISONMENT DETAINEES FROM CENTRAL AND EASTERN EUROPE IN 1945
}

\begin{abstract}
The article describes the process of detaining civilians by the agents of NKVD nad SMERSH 1 (counter-intelligence agency in the Red Army) in the years 1944-1945, when the Red Army was entering to Central and Eastern Europe. The fortunes of arrested by soviets are presented by the example of one of three crucial camps located in Siberia, where people detained in 1945 were sent; between them there were also Poles - mainly from Eastern Pomerania and Upper Silesia. It was camp number 503 with its headquarters in Kemerowo. Basic historical records used in the study are reports written by the camp's management to Main Administration for Affairs of Prisoners of War and Internees (GUPVI) and the witnesses' accounts of their stay in the camp. The article describes the organization of the camp, living conditions of the detainees, the ways of employing them in siberian industry, question of deaths and comeback of these prisoners, who managed to survive the stay in the camp.
\end{abstract}

Słowa kluczowe: deportacja, radzieckie obozy pracy, zesłanie

Keywords: deportation, Soviet labor camps, exile

\section{BIBLIOGRAFIA}

\section{Źródła publikowane:}

Teczka specjalna J.W. Stalina. Raporty NKWD z Polski 1944-1946, wybór i oprac. T. Cariewskaja, A. Chmielarz, A. Paczkowski, E. Rosowska, Sz. Rudnicki, Warszawa 1998.

\section{Wspomnienia i relacje:}

„Wywieziono nas bydlęcymi wagonami”. Relacje deportowanych z Górnego Śląska do Związku Sowieckiego w 1945 roku, wybór i opracowanie S. Rosenbaum, D. Węgrzyn, Katowice 2015.

\section{Opracowania:}

Arkusz A., Obywatele polscy w obozie NKWD-MWD ZSRR nr 178-454 w Riazaniu w latach 1944-1947, Kraków 2010.

Borkowska E.H., Dyklong U., Jonderko A., „Mieli wrócić za czternaście dni”. Mieszkańcy Ostropy w obozach pracy przymusowej w Zwiqzku Sowieckim (1945-1949), Katowice-Gliwice 2014.

Golec J., Bojda S., Steller Pawet, „Słownik biograficzny ziemi cieszyńskiej”, t. 2, Cieszyn 1995.

Golon M., Polityka radzieckich władz wojskowych i policyjnych na Pomorzu Nadwiślańskim w latach 19451947, Toruń 2001.

Holzer J., Europa zimnej wojny, Kraków 2012.

Materski W., Dyplomacja Polski ,lubelskiej” lipiec 1944 - marzec 1947, Warszawa 2007.

„Niech świat pamięta o nas...”. Losy osób deportowanych do ZSRS z terenu Górnego Ślaska w 1945 r., pod red. K. Banaś, Katowice 2016. 
Orte des Gewahrsams von deutschen Kriegsgefangenen in der Sowjetunion (1941-1956). Findbuch, DresdenKaseel-Moskau-München 2010.

Pawet Steller. życie i twórczość, część pierwsza: życie (1895-1974), pod red. A. Barnaś, Katowice 2006.

Wywózka. Deportacje mieszkańców Górnego Ślaska do obozów pracy przymusowej w Zwiazku Sowieckim w 1945 roku. Faktografia - konteksty - pamięć, pod red. S. Rosenbauma i D. Węgrzyna, Katowice 2014.

\section{Publikacje w języku rosyjskim:}

Бельков А.В., Орлов М.А., Иностранные военнопленные и интернированные как одна из волн принудительной миграции на территории Кемеровской области (1944-1950 г2.), „Вестник Вятского государственного гуманитарного университета" № 4/2005, Вятск 2005.

Государственный Комитет Обороны СССР. Постановления и деятельность 1941-1945 г2. Аннотированный каталог в двух томах, Т. 2: 1944-1945, Москва 2015.

Долголюк А., Маркдорф Н.М., Военнопленные в Сибири 1943-1955 г2. Историческое исследование и документальные материалы, часть I, Новосибирск 2014.

Долголюк А., Маркдорф Н.М., Иностранные военнопленные и интернированные в Сибири (1943-1950), Москва 2016.

Долголюк А., Маркдорф Н.М., Иностранные военнопленные и интернированные в сибирской экономике (1944-1956 г2.), „Иркутский историко-экономический ежегодник”, Иркутск 2014.

Конасов В.Б., Военнопленные и интернированные граждане Германии: путь на родину из СССР (19401950-е годы). Документы, факты, комментарии, Москва 2001.

Кузьминых А.Л., Система военного плена и интернирования в СССР. Генезис, функиионировние, лагерный опыт (1939-1956 г2.), Архангельск 2014 (na prawach rękopisu). Wersja książkowa zob. Кузьминых А.Л., Военный плен и интернирование в СССР (1939-1956 годы), Вологда 2016.

Маркдорф Н.М., Медико-санитарное обеспечение иностранных военнопленных и интернированных в лагерях и рабочих батальонах Западной Сибири: 1943-1950 гг., Вестник Омского университета, № $3(65) / 2012$, Омск 2012.

Орлов М.А., Кемеровский лагерь военнопленных и интернированых № 503 (1945-1949 г2.), „Вестник Кузбасского государственного технического университета" № 1 (101), Кемерово 2014.

Региональные структуры ГУПВИ НКВД-МВД СССР 1941-1951. Отчетно - информаиионные документы, под ред. М.М. Загорулько, Т. 5, к. 2, Волгоград 2006.

Репрессии против поляков и польских граждан, Москва 1997.

Русский архив: Великая Отечественная. Т. 24 (13), Иностранные военнопленные второй мировой войны в СССР, под ред. А.В. Золоторева, Москва 1996.

Шахтерские города Кузбасса в годы Великой Отечественной войны. Материалы региональной научно-практической конференции (Прокопьевск, 28 мая 2015 г.), Кемерово 2015. 